\title{
放射線少量照射により効果増強を計る 肺癌の化学療法について
}

\author{
Combined Chemotherapy for Lung Cancer with
}

Concurrent Small Dose Irradiation

中村慎一郎・竹永昭雄・宝来 威・池上晴通・松田 実・井上俊彦*

\begin{abstract}
抄録：従来，肺癌に対して行ってきた，多剤化学療法に，効果増強の目的で, 抗癌剂投与直前 に，少量の放射線を照射し，大幅な腫瘍効果の増強を得た。特に小細胞癌においては， 従来の有効率 $61 \%$ に比し, 100\%と, 著明な効果が得られ, 本法の有用性が確認された。
\end{abstract}

\section{はじめに}

手術不能の原発性肺癌に対しては，放射線照 射あるいは, 抗癌剂投与による治療が行われる。 しかし, 放射線単独の治療は, 組織型によって, その効果に差があり，すべての肺癌に対して有 効であるとは限らず, 又, あくまでも局所療法 であるため，遠隔転移に対しては無力である。 遠隔転移を含む進行癌については，抗癌阂によ る治療が第 1 選択ではあるが, 多剂併用療法を 用いてもなお，その腫瘍効果は不充分といわざ るを得ない現状である。

このように，放射線，抗癌剤のいずれか一方 による治療では, 満足出来る治療効果をあげる ことは困難であり, このため, 両者の適切な併 用による治療法の開発が, 現在の肺癌治療にお ける，1つの大きなテーマとなっている。

最近, 西村ら ${ }^{1)}$ は, 併用法の 1 つの型式とし て, 少量の放射線を, 抗癌剤の投与直前にのみ, 照射する方法について検討している。この方法 では，1コース中の照射量が1000rads程度と， これまでの併用法に比し，1/4〜1/5であり，併用 療法の最大の問題である副作用を大幅に軽減出

大阪府立成人病センタ一内科

* 大阪府立成人病七ンタ一放射線治療科
来ると期待されこれにより，適応が拡大され るものと思われる。

我々は, 昭和 52 年 7 月より, 従来, 当施設で 行われている抗癌剤の多剂併用療法についてこ の方法を検討し，良好な結果を得たので報告し， 併せて, その作用機序について, 若干の考察を 加える。

\section{対象と方法}

昭和 52 年 7 月より，昭和 53 年 10 月までに当科 に入院した，組織型の明らかな，未治療の原発 性肺癌患者30名 (男子 24 名, 女子 6 名) を対象と した。組織型別にみると, 扁平上皮癌 6 例, 腺 癌 11 例, 小細胞癌 10 例, 大細胞癌 3 例, うち, 巨 細胞癌 1 例)であった。臨床病期分類によれば, I 期 4 例， II 期 7 例，III 期 11例， IV 期 8 例であ る。年令は平均 $63.6 才$, 中央值66才であった。

(Table $1-4$ )

小細胞癌の治療スケ:ジュールをFig. 1 に示す. 治療は 1 週間を単位とし，第 1 日目に，病巣線 量にして200radsの放射線を照射し，その数時間 以内に抗癌剤を投与する。しかし, 初期の11例 では, 放射線照射が, 抗癌剂投与前日と, 当日 の 2 回, 100radsづつという方式になっている. 
いずれも，㸓射は速に200radsのみ である。义，1例のみ,20()rads 2 日䦌恕射のものがある。

抗将剂は，我々が徒来，初川污 療に苮用してきた組令せによる， 多剂俾肘法在行一た。即ち, Cyc一 lophosphamide $20 \mathrm{mg} / \mathrm{kg}$ 文びVin

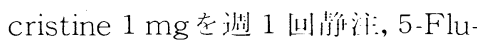

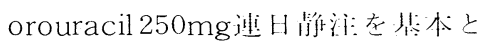

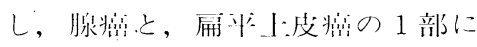
は,さらにMethotrexate15mg 逧

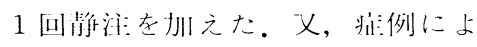
っては,Cyclosphosphamideに代え $\tau$, Carboquone $3 \mathrm{mg}$, Vincristineに代えて, ' Vinblastine $10 \mathrm{mg}$ を，义，5-Fluorouracilに代えてFu traful 15mg/kg紋山投与寺使做し た。

投与期間は 4 速間を目椯とした が, 10例は全身状態, 及び血液状 態によって投薬を中怩した。この うち 4 例は, 1 ～ 2 䢞の休薬によ

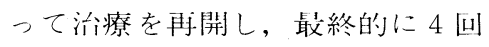
投与に萳たなかったものは，30例 中 6 例である。

効果判定は, 刖部レントゲント: での, 朠瘍陰影の面稍の減少によ

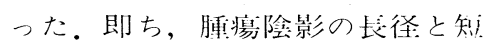
径の積が, 治療前と比較して,75\% 以上の繀少をみたものを著効 $($ 卅), 50\%以上， 75\%未淽減少をみた ものを有効 (H)，25\%以上，50\% 未満の縮少に留ったものをやや有 効 $(+), 25 \%$ 未淦の縮少であった ものを無効(一)と判定した。なお， 有効率の算定は，50\%以上の縮少 をみたものを有効群として行った。

\section{結 果}

30例全例についてみると，16例， $53 \%$ に腫瘍㓌影の $50 \%$ 以上の縮少 をみた。このうち，著効 6 例， 20
Table 1. Small cell carcinoma.

\begin{tabular}{|c|c|c|c|c|c|c|c|c|c|c|c|}
\hline No. & Case & Age & Sex & Stage & Agent & $\begin{array}{l}\text { given } \\
\text { times }\end{array}$ & $\begin{array}{l}\text { Single } \\
\text { dose }\end{array}$ & $\begin{array}{l}\text { total } \\
\text { dose }\end{array}$ & effect & $\begin{array}{l}\text { trans- } \\
\text { fusion }\end{array}$ & $\begin{array}{r}\text { survival } \\
\text { (days) }\end{array}$ \\
\hline 1 & K.O. & 66 & $\delta$ & II & EX. VCR. 5-FU. & 4 & 100 & 800 & H & - & $319 \rightarrow$ \\
\hline 2 & T.B. & 69 & $\hat{\delta}$ & IV & EX. VCR. 5-FU. & 4 & 200 & 800 & \# & + & $258 \rightarrow$ \\
\hline 3 & S. I. & 69 & f & II & EX. VCR. & 2 & 200 & 400 & H & - & $200 \rightarrow$ \\
\hline 4 & S.Y. & 62 & $\delta$ & II & EX. VCR. 5-FU. & 5 & 200 & 1000 & \# & - & $81 \rightarrow$ \\
\hline 5 & F.o. & 61 & q & N & EX. VCR. FT. & 4 & 200 & 1600 & H & - & 183 \\
\hline 6 & Y.K. & 74 & $\hat{\delta}$ & I & EX. VCR. 5-FU. & 3 & 200 & 600 & H & - & $180 \rightarrow$ \\
\hline 7 & S.M. & 63 & $\delta$ & I & EX. VCR. FT. & 4 & 200 & 800 & H & - & $81 \rightarrow$ \\
\hline 8 & S.S. & 75 & $\hat{\delta}$ & III & EX. VCR. 5-FU. & 4 & 200 & 800 & H & - & 76 \\
\hline 9 & S.M & 70 & $\delta$ & II & EX. VCR. 5-FU. & 4 & 200 & 800 & H & - & $74 \rightarrow$ \\
\hline 10 & R.K. & 63 & $\hat{\delta}$ & III & EX. VCR. 5-FU. & 2 & 200 & 600 & H & + & $68 \rightarrow$ \\
\hline
\end{tabular}

Table 2. Adeno carcinoma.

\begin{tabular}{|c|c|c|c|c|c|c|c|c|c|c|c|}
\hline No. & Case & Age & Sex & Stage & Agent & \begin{tabular}{|l|} 
given \\
times
\end{tabular} & $\begin{array}{l}\text { Single } \\
\text { dose }\end{array}$ & $\begin{array}{l}\text { total } \\
\text { dose }\end{array}$ & effect & \begin{tabular}{|l|} 
trans- \\
fusion
\end{tabular} & \begin{tabular}{|c} 
survival \\
(days)
\end{tabular} \\
\hline 1 & N.W. & 71 & $q$ & ПI & EX. VCR. MTX. & 4 & 200 & 800 & H & + & $290 \rightarrow$ \\
\hline 2 & T.K. & 51 & $\delta$ & II & EX. VCR. MTX. FT. & 4 & 200 & 800 & \# & - & $264 \rightarrow$ \\
\hline 3 & H.N. & 45 & $f$ & III & CQ. VLB. 5-FU. & 4 & 100 & 800 & + & + & $413 \rightarrow$ \\
\hline 4 & F.M. & 34 & $f$ & IN & CQ. VCR. MTX. 5-FU. & 4 & 200 & 800 & + & + & 231 \\
\hline 5 & Y.S. & 68 & $\delta$ & N & EX. VCR. MTX. FT. & 4 & 200 & 800 & + & - & $165 \rightarrow$ \\
\hline 6 & K.U. & 77 & $\delta$ & IV & EX. VCR. MTX. 5-FU. & 4 & 200 & 800 & + & + & 82 \\
\hline 7 & H.K. & 68 & $f$ & [II & EX. VCR. MTX. 5-FU. & 4 & 200 & 800 & + & - & 54 \\
\hline 8 & K.N. & 46 & $\hat{\delta}$ & IN & CQ. VCR. MTX. FT. & 4 & 100 & 800 & - & - & 312 \\
\hline 9 & K.U. & 69 & $\delta$ & III & EX. VCR. MTX. FT. & 2 & 200 & 400 & - & + & $251 \rightarrow$ \\
\hline 10 & K.K. & 77 & $\hat{\delta}$ & IN & EX. VCR. MTX. FT. & 2 & 200 & 600 & - & - & $174 \rightarrow$ \\
\hline 11 & Y.T. & 74 & $\delta$ & I & EX. VCR. 5-FU. & 4 & 200 & 800 & - & - & $165 \rightarrow$ \\
\hline
\end{tabular}

Table 3. Squamous cell carcinoma.

\begin{tabular}{|c|c|c|c|c|c|c|c|c|c|c|c|}
\hline No. & Case & Age & Sex & Stage & Agent & \begin{tabular}{|l|} 
given \\
times
\end{tabular} & $\begin{array}{l}\text { Single } \\
\text { dose }\end{array}$ & $\begin{array}{l}\text { total } \\
\text { dose }\end{array}$ & effect & \begin{tabular}{|l|} 
trans- \\
fusion
\end{tabular} & $\begin{array}{c}\text { survival } \\
\text { (days) }\end{array}$ \\
\hline 1 & Y.N. & 56 & 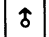 & III & CQ. VLB. 5-FU. & 4 & 100 & 600 & \# & - & 418 \\
\hline 2 & S. I. & 52 & 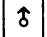 & II & EX. VCR.MTX. 5-FU. & 4 & 200 & 800 & \# & - & $252 \rightarrow$ \\
\hline 3 & H.K. & 63 & $\delta$ & N & CQ. VCR. MTX. & 4 & 100 & 800 & + & + & 132 \\
\hline 4. & C.T. & 78 & \$ & I & CQ. VCR. MTX. & 4 & 100 & 800 & - & - & 356 \\
\hline 5 & T.S: & 65 & $\delta$ & III & CQ. VLB. 5-FU. & 4 & 100 & 800 & - & + & 114 \\
\hline 6 & G.N. & 66 & $\delta$ & III & CQ. VCR. 5-FU. & 3 & 100 & 600 & - & + & 90 \\
\hline
\end{tabular}

Table 4. Large cell carcinoma.

\begin{tabular}{|c|c|c|c|c|c|c|c|c|c|c|c|}
\hline No. & Case & Age & Sex & Stage & \multicolumn{1}{|c|}{ Agent } & $\begin{array}{c}\text { given } \\
\text { times }\end{array}$ & $\begin{array}{l}\text { Single } \\
\text { dose }\end{array}$ & $\begin{array}{c}\text { total } \\
\text { dose }\end{array}$ & effect & $\begin{array}{c}\text { trans- } \\
\text { fusion }\end{array}$ & $\begin{array}{c}\text { survival } \\
\text { (days) }\end{array}$ \\
\hline 1 & U. I. & 68 & $\delta$ & II & CQ. VLB. 5-FU. & 4 & 100 & 800 & \# & - & 481 \\
\hline 2 & T. I. & 63 & $\delta$ & II & EX. VCR. MTX. FT. & 5 & 100 & 1000 & H & + & 225 \\
\hline 3 & M.K. & 44 & $\delta$ & II & EX. VCR. MTX. FT. & 6 & 100 & 1200 & + & - & $403 \rightarrow$ \\
\hline
\end{tabular}


Fig. 1. Therapeutic schedule for small cell carcinoma.

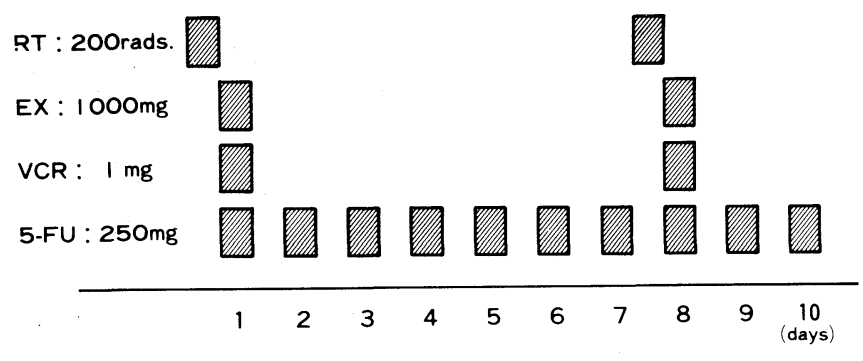

Table 5. Response rate according to cell type.

\begin{tabular}{|l||c|c||c|}
\hline & $\begin{array}{l}\mathrm{H} \\
50 \% \sim 75 \%\end{array}$ & $\begin{array}{c}\mathrm{W} \\
75 \% \sim\end{array}$ & $\begin{array}{l}\text { response } \\
\text { rate } \\
(\leq 50 \%)\end{array}$ \\
\hline $\begin{array}{l}\text { Small } \\
\text { cell Ca. }\end{array}$ & $6 / 10$ & $4 / 10$ & $100 \%$ \\
\hline $\begin{array}{l}\text { Large } \\
\text { cell Ca. }\end{array}$ & $0 / 3$ & $2 / 3$ & $67 \%$ \\
\hline $\begin{array}{l}\text { Squamous } \\
\text { cell Ca. }\end{array}$ & $2 / 6$ & $0 / 6$ & $33 \%$ \\
\hline Adeno Ca. & $2 / 11$ & $0 / 11$ & $18 \%$ \\
\hline \hline TOTAL & $10 / 30$ & $6 / 30$ & $53 \%$ \\
\hline
\end{tabular}

Fig. 2. Survival according to cell type.

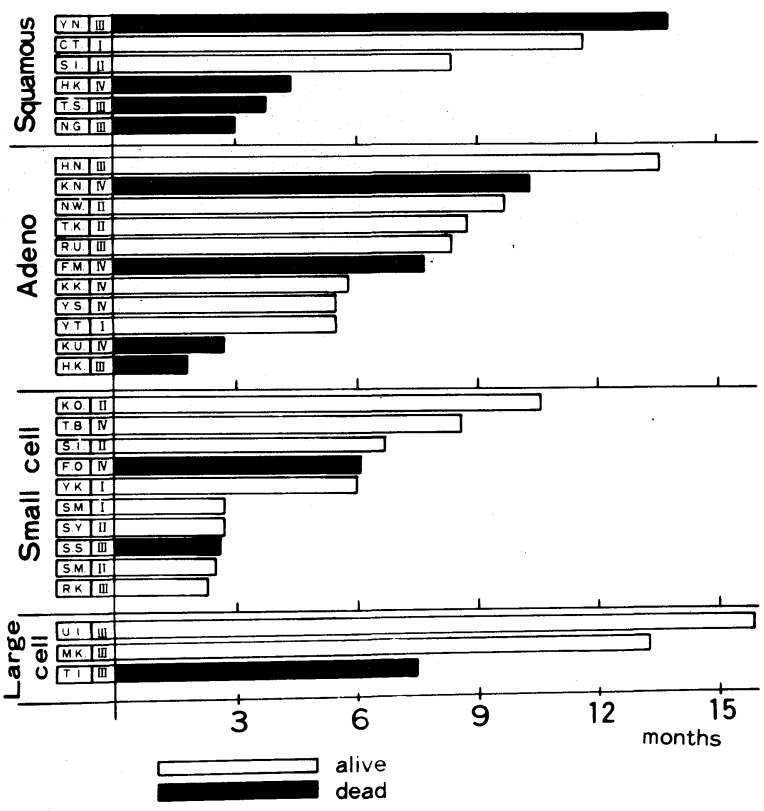

$\%$, 有效 10 例，33\%である。 $50 \%$ 以上有效率老

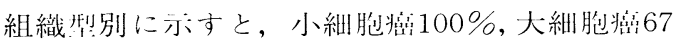
$\%$, 扁平上皮嵒33\%, 腺嵒 $18 \%$ であり，殊に小 細胞癌，大細胞媳に対して，効果は著明である。 (Table 5)

生存期間をFig. 2 に示すが, 既に30例中 11 例 が死亡している。死亡例を組織型別にみると, 小細胞嵒 10 例中 2 例, 大細胞㙖 3 例中 1 例, 扁 平上皮澺 6 例中 4 例，腺嵒 11 例中 4 例である. こ狄のうち，6ヶ月未蔳で死亡したものは，

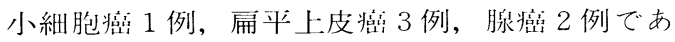
り，20\%が生存期間 6 ケ月未瀮である。一方,
Fig. 3. Peripheral blood cell count during therapy (Mean \pm S.D.).

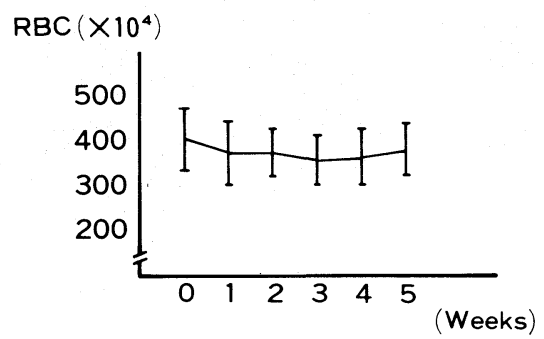

WBC
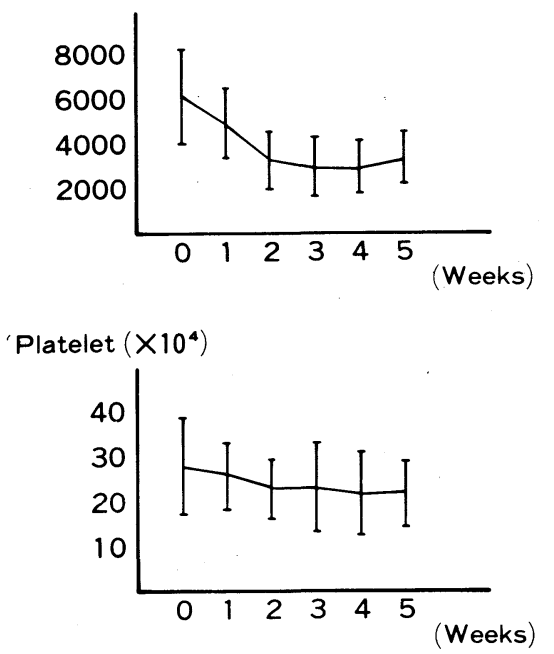

死亡症例を，有効症例，無効症例別にみると， 有効 16 例中 4 例，25\%，無効14例中 7 例，50\% となる。さらに著効 6 例についてみると, 1 例 のみが死亡で, 残り 5 例中 4 例は, 6 个月を超 えて生存中である。

副作用で最も問題となるのは筲䯙抑制であり, 末梢血球数の変動をFig. 3 に示す.

赤血球，血小板は，治療中軽度の減少傾问を 
示すが，臨床上問題とはならなかった。一方白 血球は第 3 , 第 4 週に最低となり, 平均 2500 と, 治療前の約 $1 / 2$ の值になっている。30例中 7 例が 白血球数 2000 以下となり，この7 例を含め, 11 例に新鮮血輸血を行っている.

その他の副作用として, 主にCyclophosphamideによると思われる悪心，嘔吐がほぼ全例にみ られたが，投与後数日で回復し，次回治療に支 障はなかった，又，軽度の脱毛もほぼ全例に認 められたが，治療の終了後，回復した。

放射線による食道炎，肺線維症等は出現せず， 放射線宿酔毛見られなかった。

\section{考案}

手術不能の原発性肺癌に対する治療は, 遠隔 転移の危険が存在する以上, 抗癌剤がその中心 とならねばならない。しかし，初回治療を抗癌 剂のみで行った場合, 最も良好な反応を示す小 細胞癌の場合でも, その腫瘍縮少効果は, 本邦 のCOMP療法による79\%, 米国でのCTX+MT$\mathrm{X}+\mathrm{CCNU}$ による $92 \%,{ }^{3)}$ の有効率に留っている のが現状である。抗癌剤の腫瘍効果を高めるた めの手段としては，放射線との併用が，現時点 で最も有望であり, Hansen, ${ }^{4)}$ 太田 ${ }^{5)}$ の報告にみ る様に, 両者の併用は, 著明な効果壃強をもた らす。しかし, 両者をFull doseで併用すること は，副作用の増大のため，適応に制限が生じる。 従って, より副作用の軽微な併用法の確立が望 まれる。

今回, 我々は, 抗癌剂の投与直前に少量の放 射線を照射するという方法を採ったが，先に示 した様に, 特に小細胞癌, 大細胞癌において, 著明な効果增強を得ている。即ち, 小細胞癌に おいては, 我々の施設で, 同一の薬剂を放射線 照射なしに投与した場合の有効率 $61 \%$ ( 23 例中 14 例）に比し,100\%(10例中10例) と, 大幅な有効率 の上昇を得ている.小細胞癌においては, 腫瘍 効果の良好なもの程生存期間も長いという事は, 多くの報告で認められており，6),7),8)本法による 100\%の有効率の達成は極めて有意義であると考 える. 又, 大細胞癌症例のうち, 著効を示した 1 例は, 従来, 如何なる治療にも抵抗し, 悪性
の䋂迵をたどると考えられた ${ }^{91,10), 11)}$ 巨細胞癌症 例である。この症例は，䏫部レントゲン上，ほ ぼ完全に腫痬㓌影が消失し，治療開始後 1 年 4 ケ月の現在，生存中である。

扁平上皮癌，腺癌については，期待した程の 効果は得られていない。

扁平上皮癌の無効症例中 2 例に巨大な空润を 形成し，いずれもPseudomonasによる感染が死 因となっている。これは腫瘍に対する効果とし ては，むしろ強すぎると洃えられ，評価すべき ものとは思われるが，腫瘍形成に加えて，喀血 の危険を伴うことから，有効症例からは除外し

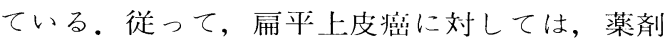
を減量し，回数を重ねる方们で検討中である。

腺隐に対しては，むしろ，より強力な多剂併 用療法が必要ではないかと将えているが,これ は, Full doseの放射線治療との同時併用との関 連において，更に検討が必要であろう。

Dose limiting factorとなった副作用は，筒髄 抑制であり，約 $1 / 3 ， 11$ 例に輸血を行っているが, これら輸血を要した症例は，小細胞癌で10例中 2 例，その他 20 例中 9 例であるので，少量同時 併用の放射線の影響というよりは，使用された 抗癌剤に主因があると考えられる。その他の放 射線に起因すると考えられる副作用は認めてお らず，併用療法としては，極軽度の副作用 であるといえる。

本法の作用機序として, 西村ら ${ }^{1)}$ は, 放射線 による腫瘍細胞膜の透過性の元進を想定してい

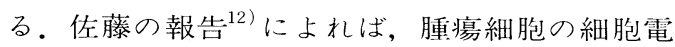
気泳動度は, 100radsの放射線照射後，4時間を ピークに減少を示している。細胞の電気泳動度 は，主として膜の陰性荷電によるものであるの で，腫瘍細胞膜に何らかの変化が生じているの は，確実のようである。

一方, 腫瘍細胞のDNAにおいては, 放射線に よるdamageからの回復が行われる。即ち, sublethal damageよりの回復(Elkind回復)は，照射 後3時間で終了し, lethal damageよりの回復 (potential lethal damage[P.L.D.]回復)は，6時間 で終了する . ${ }^{13)}$ 従って, 放射線照射後数時間は, 腫瘍細胞のDNAは，修復の過程にあり，極めて 
不安足芜であると想像される。この様な，放射線 照射直後の，腄瘳維胞膜，DNAの其に不安定ま 時期に，抗猫剂を大丝に投与古ることにより， 従来期待していた以上の効果が得ら狄るのでは ないかと, 考えている。

作用機序に関する以上の様な仪説を前提とす れば，抗将剂投与の夕イミングは，照射後 3 時 間以内という事になるが，二狄は臨床上老分実 行可能である。次に至適照射線量が問題となる。 我々は邈 1 回200radsを照射しているが,これが 適当か否かは更に唡討を要する。線肆を坮せば 副作用が增加し，減ずれしば效果の減少を招く恐 狄がある。

本法の延命効果は, 期間も知く, 症例も少い ため, 評価の段階ではなく，現在，小細胞狛を 中心に，症例を重ね娭討中である。しかし，㽽 患者の延命を計るためには，莫解筞入，維持， 強化の一連のコースが必要であるというのが最 近の傾问であり，副作用の比較的軽微で，優れ た腫瘍効果を持つ本法の宽解奨入療法としての 役割に期待される所は大きい。特に, 高令, 呼 吸機能障害等でFull doseの放射線照射が困難で ある場合や，肺j門，縦隔の腄瘍でFull doseの照
射により食道炎の発現が示想される埸命，更に，

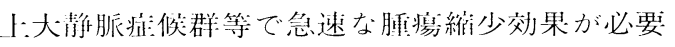
である埸命等が，最も良い適応となると考えら れる。

\section{まとめ}

手術不能の原発性肺谣に対して, 多剂化学療 法の效果曙強を目的として，少量の放射線を， 抗缸剂投与数時間前に照射することによって，

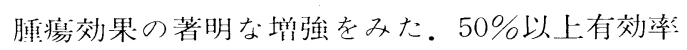

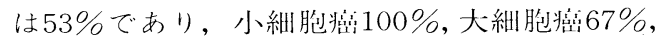

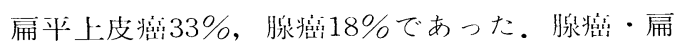
平上皮嵒については，なお娭討の余地があるが， 局所效果に重点を扔いた治療法としては, 本法

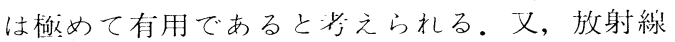
の併用による副作用の增強は見られなかった。

税を終えるにあたり，御校閲を頂いた大阪府 立成人病センタ一研究所言服部正次博士に心よ り感謝致します。

本研究は, 厚生省がん研究助成金 $(52-5)$ に よって行われた。

\section{文 献}

1) 西村 譲, 他：癌と化学療法, 4：1291, 1977.

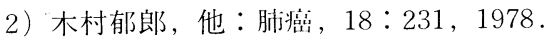

3) Selawry, O.: Lung Cancer(ed. Straus)217, Grune \& Stratton, 1977.

4) Hansen, H. et al:Cancer, $30: 315,1972$.

5) 太田和雄, 他：嵒の臨床, 17 :269, 1971.

6）服部正次，他：肺诺山，18：419，1978.

7) Gilby, E. D. et al:Cancer, 39: 1959, 1977.

8) Edmonson, J. H. et al:Cancer Treatment Reports, $60: 925,1976$.
9 ) Broderick, P. A. et al:Acta Cytologica, 19:225 1975 .

10) Metropol, H. J. et al:The American Surgeon $31: 206,1965$.

11) Hathaway, B. M. et al:Arch Surg, 98:24, 1969.

12) 佐藤周子：癌と化学療法, 5 ：311, 1978 .

13）坆本澄彦: 嵒の放射線生物学, 中外医学社, 1978. 


\title{
Combined Chemotherapy for Lung Cancer with Concurrent Small Dose Irradiation
}

\author{
Shinichiro Nakamura, Akio Takenaga, Takeshi Horai, \\ Harumichi Ikegami, Minoru Matsuda, Toshihiko Inoue*. \\ Center for Adult Diseases, Osaka \\ Department of Internal Medicine. \\ *Department of Radiotherapy.
}

30 patients of unresectable primary lung cancer were treated with polychemotherapy and small dose irradiation concurrently. Intermittent small dose irradiation was used on purpose to sensitize the tumor cells to the effect of the chemotherapy. Patients were irradiated 200 rads on day 1 , immediately before the intravenous administration of anticancer agents. (for example, Cyclophosphamide $20 \mathrm{mg}$./kg., Vincristine $1 \mathrm{mg}$., 5-Fluorouracil $250 \mathrm{mg}$. in small cell carcinoma.) From day 2 to day 7, patients were given $250 \mathrm{mg}$. of 5-Fluorouracil intravenously. Therapy was continued for 4 weeks, and the effect was evaluated on chest X-ray films. Regression of tumor size more than $50 \%$ calculated by product of two perpendicular diameters was defined as an objective response.

Overall response rate was $53 \%$. The response rate in relation to cell type was, $100 \%$ in small cell carcinoma(10/10), 67\% in large cell carcinoma(2/3), 33\% in epidermoid carcinoma(2/6), and $18 \%$ in adenocarcinoma(2/11).

No remarkable side effect to the addition of small dose irradiation was observed. 